\title{
Prevalence of Burnout among Professionals Who Care for Elderly and Chronically Ill Patients
}

\author{
Carla Susana Vicente ${ }^{1}$, Rui Aragão Oliveira ${ }^{2}$, João Maroco ${ }^{2}$ \\ ${ }^{1}$ Department of Clinical Psychology, University of Évora, \\ Évora, Portugal \\ ${ }^{2}$ Doctorate, Research Unit in Psychology and Health (UIPES), Higher Institute of Applied Psychology, \\ University Institute (ISPA), Lisbon, Portugal \\ Email: csvicent@gmail.com
}

Received 21 September 2014; revised 16 October 2014; accepted 12 November 2014

Copyright (C) 2014 by authors and Scientific Research Publishing Inc.

This work is licensed under the Creative Commons Attribution International License (CC BY). http://creativecommons.org/licenses/by/4.0/

c) (i) Open Access

\begin{abstract}
This study aims to evaluate the prevalence of Burnout Syndrome among professionals who care for elderly and chronically ill patients and the relationship between the appearance of Burnout and sociodemographic and job related variables. The sample consisted of 265 employees who worked directly with the elderly and chronically ill. It was composed mostly of women, $94.3 \%$. The average age was 43 (SD $=10.2$ ). We made use of the following instruments: a sociodemographic questionnaire and the Maslach Burnout Inventory-HSS (Semedo, 2009). The results show that $19.6 \%$ of participants have high rates of emotional exhaustion, $4.9 \%$ present high depersonalization, and $2.6 \%$ experience low personal accomplishment. Disease severity and support services influence personal accomplishment. Age proved to be a predictor of the emotional exhaustion variable, while the length of service at an institution variable not only proved to be a predictor of emotional exhaustion, but also of personal accomplishment. The prevention of Burnout Syndrome constitutes one of the major challenges for occupational health care providers to the elderly and chronically ill.
\end{abstract}

\section{Keywords}

Burnout Syndrome, Emotional Exhaustion, Social Work, Health Care Professionals, Geriatric

\section{Introduction}

The bankruptcy of social and health policies, as well as demographic aging, has contributed to a growing de- 
mand for a response from social institutions directed at the elderly. These combined aspects have resulted in greater pressure, from the users, for professionals to solve complex social situations. The objective for social workers is to help people in physically, mentally or socially vulnerable situations. In addition to these demands, care providers are further confronted with a lack of social recognition, and a scarcity of economic and/or human resources, which would otherwise allow them to adequately respond to the situations with which they are faced. On many occasions, these professionals feel that the work they do doesn't coincide with their original expectations regarding their profession and, that many times, they carry out roles and tasks they feel unprepared for, which may lead to a certain frustration (Barría, 2003; Lyod \& King, 2004). This state of affairs may lead to the onset of psychosocial risks, namely an increase in stress, and consequently to serious deterioration of mental and physical health, with particular emphasis on burnout syndrome.

Burnout has come to be conceptualized as an individualized experience of stress, developing in professional contexts of complex social relationships. According to Maslach and Jackson (1981), the syndrome is associated with "physical and emotional fatigue, leading to a loss of motivation at work, that can evolve until feelings of inadequacy or failure appear” (Maslach, Schaufeli, \& Leiter, 2001). It is characterized as a multidimensional phenomenon comprising three dimensions: emotional exhaustion, depersonalization, and diminished personal accomplishment. Emotional exhaustion is understood to imply a depletion of the individual's emotional, moral and psychological resources. Depersonalization represents a dehumanization of the relationship with the other, namely those who are the raison d'être of the profession (patients/clients). Personal accomplishment refers to a decrease in sentiments of competence and pleasure associated with carrying out the profession (Beihl \& Nunes, 2012; Gisbert, Los Fayos, \& Montesinos, 2008; Schaufeli, Leiter, \& Maslach, 2009).

The incidence of burnout is one of the aspects that has most contributed to an increase in empirical studies in a variety of countries and contexts. However, discrepancies have been observed in the results obtained. Reflecting this, for example, are the studies undertaken in England, Spain and Portugal. In a study conducted in England, the results obtained were substantially high, in so far as 33\% presented high emotional exhaustion, $17 \%$ presented high depersonalization and 36\% reported low personal accomplishment (Oyefeso, Clancy, \& Farmer, 2008). In Spain, studies like those by Grau, Suñer \& García (2005), Noguera \& Francês (2008), report similarly high levels for both emotional exhaustion (40.6\% and 42.6\%), and depersonalization (23\% and 43.5\%). Although lower than in the previous dimensions, the results regarding the personal accomplishment dimension were situated between $24.3 \%$ and $38.6 \%$. Considering the empirical studies undertaken in Portugal, we observed a substantially lower incidence of burnout compared to England and Spain. Varoli \& Souza (2004), in a study involving mental health professionals, ascertained that 20.6\% presented high emotional exhaustion, 5.2\% high depersonalization, and 3.5\% low personal accomplishment. Nevertheless, Silva and Gomes (2009), Ribeiro, Gomes \& Silva (2010), in a study also involving health care professionals, reported lower levels, given that, for the emotional exhaustion dimension, figures oscillated between $6 \%$ and $9.8 \%$, with low personal accomplishment situated between $1 \%$ and $2.8 \%$. The results of the depersonalization dimension were similarly low, varying between 1\% and 1.4\%. While the results presented by Gomes, Cruz \& Cabanelas (2009) for the depersonalization (4\%) and personal accomplishment (1\%) dimensions don't differ from previous studies, the rate of emotional exhaustion (15\%) was more pronounced.

On the other hand, the importance of factors which encourage or trigger burnout has been emphasized. Specifically, organizational aspects are referred to, with greater attention given to the professional environment, degree of autonomy, execution of tasks, social support, role ambiguity and lack of reciprocity (Kareaga, Exeberria, \& Smith, 2008; Semedo, 2009). The importance of job content has not been neglected, given the fact that many of these professionals are confronted, on a daily basis, with pain, suffering and death; as well as dealing with patient's feelings and with those of respective family members (Da Silva, Marques, \& Da Silva, 2009; Gisbert et al., 2008).

Within the scope of factors related to the individual, studies highlight the importance of gender, age, marital status, personality characteristics and coping strategies. In relation to gender, research differs to the extent that, in some studies the inference is that women present higher levels in the emotional exhaustion dimension while, for men, the highest levels were evident in the depersonalization dimension. In others, these differences in score were not so evident (Carlotto, 2011; Dias, Queiros, \& Carlotto, 2010; Ebling \& Carlotto, 2012; Grau, Flichtentrei, Suñer, Prats, \& Braga, 2009). In relation to age, while it is recognized that burnout may affect professionals of any age, the majority of studies report that it is younger individuals who show a greater propensity for the syndrome (Ebling et al., 2012; Grau et al., 2009). On the other hand, research indicates that a greater number of 
working hours also corresponds to more pronounced levels of emotional exhaustion and depersonalization in professionals, with evidence that professionals working longer hours (42 hours per week), present higher levels of emotional exhaustion (Gisbert et al., 2008).

Although there is a large body of literature on burnout syndrome, this research is considered pertinent due to the scarcity in Portuguese studies dealing with the prevalence of burnout syndrome in care providers to elderly and chronically ill patients. The following objectives were defined: a study of the prevalence of burnout syndrome in professionals who provide care to elderly and chronically ill patients, and the relationship between the appearance of burnout and the variables: sociodemographic, with particular emphasis on the severity of the illness, and the influence of the institutionalization variable in the occurrence of the burnout phenomenon.

\section{Method}

\subsection{Research Design}

We conducted a cross-sectional study and descriptive-correlational, using quantitative methodology.

\subsection{Sample}

The study was undertaken at Private Social Solidarity Institutions (IPSS'S), which had recourse to the following social resources: a day care center, home care, residential care and continuing care. The following criteria were defined: a minimum of 12 months of service; direct work with the elderly and chronic disease.

Thus, the sample was composed of 265 participants, who agreed to participate voluntarily in this study. The majority were women $94.3 \%(n=250)$, and only $5.7 \%(n=15)$ of the participants were men. The average age was $43.04(\mathrm{SD}=10.2)$. With respect to marital status, $58.9 \%$ were married and $36.9 \%$ single or divorced. With regard to academic qualifications, 32.5\% had obtained a high school qualification (7th and 9th grade) and 21.5\% had a Bachelors (19.2\%) or Master's degree (2.3\%).

The average seniority was 9.03 years $(\mathrm{SD}=7.7)$, and $7.57(\mathrm{SD}=7.1)$ for length of service at an institution. Standard full-time hours proved most prevalent (50.9\%), and only $3.8 \%$ of the subjects worked part time. The most representative support services were: residential care (34.7\%) and home care (33.2\%). The most common illnesses the professionals dealt with were: neurological illnesses (98.5\%), diabetes (96.2\%), rheumatic illnesses (84.5\%), respiratory illnesses (80.4\%) and oncological disease (75.1\%).

\subsection{Measures}

The sociodemographic questionnaire, which allowed for a characterization of the participants, was elaborated on a basis of closed questions.

The objective of the Maslach Burnout Inventory-Human Services Survey (MBI-HSS) (Semedo, 2009; Maslach \& Jackson, 1996) is to evaluate burnout in workers in the social and human services field. In its original version, it is composed of 22 items about feelings related to the job, distributed along 3 scales: emotional exhaustion, with 9 items; depersonalization, with 5 items, and personal accomplishment, with 8 items. The answer is based on the frequency with which each feeling occurs on an ordinal scale of 7 points between "Never" (0) and "Every day" (6). The internal consistency of the emotional exhaustion (0.84) and personal accomplishment dimensions (0.70) of the MBI-HSS was acceptable, with the exception of the depersonalization factor which presented low internal consistency (0.59) (Vicente, Oliveira, \& Maroco, 2013).

\subsection{Procedures}

The formal contact was made with the boards of the Private Social Solidarity Institutions, having sent by electronic mail the requests for collaboration in the respective study. Together with the introductory letter for the study, in annex was a request for permission, which included the objectives and phases of the study. Sample collection was carried out between January and March of 2011.

In order to ensure the anonymity and confidentiality of the participants, each participant received an envelope which included the objectives of the study; informed consent, the sociodemographic questionnaire, the Maslach Burnout Inventory-Human Services Survey (MBI-HSS). The participants were assured of the anonymity of their answers, and no remuneration or incentive of any kind was offered to the participants. All of the procedures required by the Research Ethics Committees were followed. 


\subsection{Statistical Analysis}

We used descriptive statistics to characterize the study variables (Table 1).

The analysis of variance "One-Way" (ANOVA) followed by comparisons "post-hoc" and "t-tests" for independent samples, for a type I error probability of 95\%, were used to infer the existence of differences in averages of sociodemographic variables under study.

In order to identify the levels of burnout, it was considered the frequency of symptoms, up three "a few times a month" for emotional exhaustion and depersonalization, and two for the personal accomplishment, according to proposed by Shirom (1989) because non-existence of validated cut-off points for the Portuguese MBI-HSS population.

Table 1. Comparison between the MBI-HSS dimensions and the variables in study.

\begin{tabular}{|c|c|c|c|c|c|c|c|}
\hline \multirow{2}{*}{ Variable } & \multirow{2}{*}{$\mathrm{n}$} & \multicolumn{2}{|c|}{$\mathrm{EE}$} & \multicolumn{2}{|c|}{ DP } & \multicolumn{2}{|c|}{ PA } \\
\hline & & $M$ & $S D$ & $M$ & $S D$ & $M$ & $S D$ \\
\hline \multicolumn{8}{|l|}{ Gender } \\
\hline Masculine & 15 & 1.6 & 1.4 & 0.9 & 1.0 & 5.4 & 0.4 \\
\hline Feminine & 250 & 1.5 & 1.1 & 0.7 & 0.8 & 5.2 & 0.7 \\
\hline \multicolumn{8}{|l|}{ Marital Status } \\
\hline Single & 51 & 1.8 & 1.4 & 0.7 & 0.8 & 5.1 & 0.8 \\
\hline Married/de facto union & 156 & 1.4 & 1.0 & 0.7 & 0.8 & 5.2 & 0.7 \\
\hline Widowed & 58 & 1.5 & .9 & 0.9 & 1.0 & 5.4 & 0.5 \\
\hline \multicolumn{8}{|l|}{ Academic qualifications } \\
\hline Primary School & 43 & 1.2 & 1.0 & 0.9 & 0.9 & 5.2 & 0.7 \\
\hline High School & 39 & 1.7 & 1.1 & 0.7 & 0.8 & 5.3 & 0.5 \\
\hline Honour's/master's Degree & 57 & 1.8 & 1.2 & 0.5 & 0.5 & 5.2 & 0.5 \\
\hline \multicolumn{8}{|l|}{ Working hours } \\
\hline Extra hours & 120 & 1.5 & 1.1 & 0.8 & 0.9 & 5.1 & 0.7 \\
\hline Normal & 135 & 1.5 & 1.2 & 0.6 & 0.8 & 5.3 & 0.6 \\
\hline Part time & 10 & 1.7 & 0.9 & 0.5 & 0.4 & 5.3 & 0.5 \\
\hline \multicolumn{8}{|l|}{ Contractual situation } \\
\hline Permanent staff & 199 & 1.8 & 1.1 & 0.8 & 0.9 & 5.2 & 0.7 \\
\hline Service providers & 12 & 1.5 & 1.2 & 0.4 & 0.4 & 5.3 & 0.5 \\
\hline \multicolumn{8}{|l|}{ Age } \\
\hline 25 - 30 years & 26 & 2.0 & 1.2 & 0.6 & 0.7 & 5.1 & 0.5 \\
\hline 31 - 35 years & 39 & 1.8 & 1.4 & 0.7 & 0.9 & 5.2 & 0.7 \\
\hline 50 - 55 years & 37 & 1.2 & 0.9 & 0.8 & 0.8 & 5.3 & 0.7 \\
\hline \multicolumn{8}{|l|}{ Length of service at an institution } \\
\hline 5 - 10 years & 49 & 1.5 & 1.2 & 0.7 & 0.8 & 5.4 & 0.6 \\
\hline$>10$ to 15 years & 40 & 1.6 & 1.0 & 1.0 & 1.1 & 5.3 & 0.5 \\
\hline$>15$ to 20 years & 14 & 1.7 & 1.2 & 0.8 & 0.9 & 5.0 & 0.7 \\
\hline$>20$ to 25 years & 6 & 2.0 & 1.5 & 0.5 & 0.4 & 4.6 & 1.3 \\
\hline \multicolumn{8}{|c|}{ Length of service to the elderly and chronically ill } \\
\hline 5 - 10 years & 47 & 1.5 & 1.2 & 0.7 & 0.9 & 5.4 & 0.6 \\
\hline$>15$ to 20 years & 23 & 1.7 & 1.2 & 0.8 & 0.9 & 5.1 & 0.7 \\
\hline
\end{tabular}

Note: $\mathrm{EE}$ = emotional exhaustion; $\mathrm{DP}$ = depersonalization; $\mathrm{PA}$ = personal accomplishment. 
To assess the influence of study variables, severity of disease and support services, the three dimensions of burnout were conducted multivariate analyzes of variance (MANOVA) with fixed effects (Maroco, 2010). For the variable severity of disease, were considered age, length of service at an institution, seniority, as covariates. The homogeneity of variance-covariance assumption in each group was evaluated with the test Box's $M$ test ( $M$ $=131.37 ; F(66,2493.48)=1.605 ; p=0.002)$. For the variable support services, it was decided to consider the model as covariates: age, length of service at an institution, seniority, academic qualifications, employment at an alternative place of work, and contractual situation. The homogeneity of variance-covariance assumption in each group was evaluated with the test $M$ for $\operatorname{Box}(M=55.75 ; F(24,1355.79)=2.081 ; p=0.002)$.

In both cases, there was one of the MANOVA assumptions was violated, namely variance homogeneity, given the robustness of Pillai's trace, we opted for recourse to MANOVA, in virtue of its presenting lesser probabilities of error type I and greater power than the nonparametric alternatives (Maroco, 2010).

Several multiple linear regressions (stepwise method) were carried out, using as dependent variables each dimension of burnout, to determinate if the variables age, length of service at an institution and seniority are predictors of burnout in caregivers of elderly and chronically ill.

All statistical analyses were performed with SPSS (v.17, SPSS an IBM company, Chicago, IL).

\section{Results}

The prevalence of Burnout Syndrome-one of the objectives of this study-was established with Shirom's (1989) cut-off point as its basis. In accordance with the results obtained, we verified that, in this sample, 19.6\% of the participants presented high levels of emotional exhaustion, $4.9 \%$ presented high depersonalization and only $2.6 \%$ demonstrated low personal accomplishment.

The descriptive characterization of the psychological, social and professional aspects associated with Burnout phenomenon in care providers, is reflected in Table 1 , where the averages and respective standard deviations are given.

In view of the differences between averages of one of the variables under study-that of gender —analyses of t-student were carried out for independent samples. In accordance with the analyses undertaken, no statistically significant differences were noted between men and women in any of the three burnout dimensions (EE: $t$ (263) = $-0.538, p=0.591,95 \% \mathrm{CI}]-0.780,0.445$ [DP: $t(263)=-1,003, p=0.317,95 \% \mathrm{CI}]-0.692,0.225$ [PA: $t(263)=$ $-0.902, p=0.368,95 \% \mathrm{CI}]-0.551,0.205)$.

In turn, through “One Way” ANOVA, only worth noting is the existence of statistically significant differences in the variables: working hours, contractual situation and length of service at an institution. On analyzing the working hours variable, we verified that differences are apparent only in the depersonalization dimension $(F$ $(2,2)=3.378, p=0.036, \eta 2 p=0.025$, Power $=63.4 \%)$. After a consideration of the effect of the working hours, we verified that the subjects who work overtime present greater depersonalization than those working a normal schedule $(M=0.8, S D=0.9, M=0.6, S D=0.8$, respectively).

In reference to the contractual situation variable, we verified the existence of differences in at least two dimensions, emotional exhaustion, $(F(2,5)=4.442, p=0.013$, $\eta 2 p=0.033$, Power $=76 \%$, and depersonalization $(F(2,2)=3.747, p=0.025, \eta 2 p=0.028$, Power $=68.2 \%)$. The differences observed demonstrate that tenured workers present greater emotional exhaustion and depersonalization than subjects working on a contract basis $(M=1.8, S D=1.1, M=0.8, S D=0.9$, respectively).

Regarding the length of service at an institution variable, worth noting is the existence of differences in the personal accomplishment dimension only $(F(5,1)=2.506, p=0.031, \eta 2 p=0.046$, Power $=77.9 \%)$. Proceeding with a comparison of averages, we verified that subjects with a length of service between 05 and 10 years were those who presented lesser personal accomplishment compared to those situated between 20 and 25 years $(M=5.41, S D=0.6 ; M=5.2, S D=1.2$, respectively).

To the second research question, the relationship between the burnout syndrome and the severity of illness, MANOVA revealed that the "severity of illness" factor has a medium but marginally significant effect on the multivariate composite $(\mathrm{V}=.367, F(75,70)=1.310, p=0.047, \eta 2 p=0.122$, Power $=100 \%)$. On analyzing the results, we verified that the severity of illness factor influences only the personal accomplishment dimension $(F$ $(25,79)=1.640 ; p=0.032, \eta 2 p=0.149$, Power $=97.6 \%)$, demonstrating no influence whatsoever on the emotional exhaustion dimension $(F(25,12)=0.983 ; p=0.491 \eta 2 p=0.095$, Power $=79.8 \%)$ or on depersonalization $(F(25,95)=1.293 ; p=0.166, \eta 2 p=0.121$, Power $=91.9 \%)$.

The third research question involved studying the influence of the support services in the burnout syndrome. 
MANOVA revealed that the "support services" factor had a medium but marginally significant effect on the multivariate composite $(\mathrm{V}=.077, F(12,77)=1.685, p=0.065, \eta 2 p=0.026$, Power $=86.5 \%)$. In accordance with the results, we verified that the support services factor influences only the personal accomplishment dimension $(F(4,13)=2.665 ; p .=0.033, \eta 2 p=0.040$, Power $=73.8 \%)$, revealing no influence whatsoever on the emotional exhaustion dimension $(F(4,14)=1.182, p .=0.319, \eta 2 p=0.018$ Power $=36.9 \%)$ or on the depersonalization dimension $(F(4,05)=0.784 ; p=0.537, \eta 2 p=0.012$, Power $=25 \%)$.

Other objective was investigated whether the variables age, length of service at an institution and seniority are predictors of burnout in caregivers of elderly and chronically ill. With recourse to multiple linear regression, it was possible to identify, that both the age variable and the seniority variable are significant predictors of the emotional exhaustion dimension. In accordance with the results, it is evident that the age variable has an influence on the emotional exhaustion variable, in so far as with an increase in age we observe a decrease in the emotional exhaustion variable $(\beta=-0.210, t(260)=-2.9, p=0.004)$. On the other hand, it is perceptible that an increase in the length of service at an institution variable has a positive influence on the emotional exhaustion variable $(\beta=0.287, t(260)=3.1, p=0.002)$. While length of service at an institution is only marginally significant as a predictor of the personal accomplishment dimension, it should not be ignored in so far as it exercises a contradictory influence, that is, to the extent that length of service at an institution increases, personal accomplishment of the participants appears to diminish $(\beta=-0.175, t(260)=-1.8, p=0.059)$.

\section{Discussion}

The burnout syndrome has been one of the most studied psychosocial risks, at both a national and international level, due to the pronounced implications for professionals, not only at a physical but also at a psychic level, affecting in this way the quality of life of these professionals.

The prevalence of burnout syndrome in our sample was lower than that reported by most studies. However, consistent with studies developed by Pera \& Serra-Prat (2002), Varoli \& Souza (2004), Gomes, Cruz and Cabanelas (2009), Pereda-Torales et al. (2009), whose work maintains that the incidence of Burnout in health care professionals and assistance services is situated between 10 and $20.6 \%$ in the emotional exhaustion dimension, being significantly inferior in the depersonalization dimension (4\% to $5.2 \%$ ) and low personal accomplishment (3.5\% to 6.6\%). The justification for our results, in the emotional exhaustion dimension (19.6\%), may be in fact being a context in which professionals are confronted daily with complex social situations. In addition, feelings of frustration are common due to the performance of tasks and roles for which they do not feel adequately prepared. The low results (4.9\%), in depersonalization dimension, could be due to a certain social desirability effect in relation to the responses given by the participants, in so far as a certain level of depersonalization could represent a psychological threat to the individual, in particular in those professionals whose main professional objective is care for the other (Vicente et al., 2013).

The gender variable has been considered by empirical studies as one of the most predictors of Burnout. Authors like Schaufeli \& Greenglass (2001), Carlotto (2011) have observed that women present higher levels of emotional exhaustion, while in men there is evidence of higher depersonalization. In our study, this variable was similarly considered. Although, on first analysis our results indicated that men presented higher levels of Burnout than women, no significant differences were confirmed for any of the MBI-HSS dimensions. These results, despite being in contradiction with the majority of research, are actually consonant with other studies, which in accordance with our results; also do not demonstrate the influence of the gender variable (Dickinson et al., 2007). In our understanding, these results may be due to the composition of the sample, in so far as this is a field, in the main, populated by women, thereby not allowing for evidence of the effect of the gender variable. In addition, we agree with Maslach (1998), who notes that when the gender and type of profession variables are controlled, as in our study, differences due to gender tend to disappear.

Regarding the working hours variable, studies show that a greater number of working hours per week also contribute to more pronounced levels of emotional exhaustion and depersonalization, having found that professionals working overtime demonstrate higher levels of emotional exhaustion. However, our results were in agreement with those observed by Gisbert et al., 2008 and Gomes et al., 2009, given that subjects who work extra hours present higher depersonalization when compared with those who work a normal schedule. What could justify these results is the fact that the longer the working hours, the greater the contact of these professionals with occupational stressors. These are professionals who work with people suffering from greater physical, 
mental and social vulnerability, and who sometimes recognize their incapacity, to provide adequate responses to the situations with which they are confronted. In this sense, depersonalization can be understood as a defense mechanism, providing the necessary distance so that they may deal with their work.

While it is recognized that Burnout can affect professionals of any age, studies developed by Varoli \& Souza (2004), Grau et al. (2005), Carlotto (2011) report that it is younger professionals who are more likely to develop this syndrome. On analyzing our research, we saw that the age variable presents as a predictor of the emotional exhaustion dimension that perceptibly, with an increment in age there is a reduction in emotional exhaustion. In this way, we can claim that our results are in line with those previously presented, that is, younger professionals appear to demonstrate higher levels of emotional exhaustion. We also believe that these results may be the result of the fact that younger professionals do not possess effective strategies for dealing with the demands and expectations of their jobs.

Still, the study realized by Carvalho et al. (2006) found that the age and seniority variables correlated significantly with the cynicism scale (equivalent to depersonalization). These results were in disagreement with those obtained by us, as we verified that both age and seniority were significant predictors for the emotional exhaustion dimension, although they had no effect on the depersonalization dimension. These results are supported by the research of Dias et al. (2010), who consider that age appears to play a moderate role in relation to burnout.

In relation to the variables severity illness and support services, our results were substantially modest, in so far as they appear only to correlate with the personal accomplishment dimension, without observable influence on other dimensions. In our understanding, the weak influence of these variables is explicable by the composition of the sample, which was not homogeneous.

Our research reveals some limitations which demand attention. In first place, the fact that the questionnaires were self-administered, namely the Maslach Burnout Inventory (MBI-HSS); given the participants low levels of schooling, this may have led to doubts in the filling out of this instrument. The low internal consistency (0.59) of the depersonalization dimension of the Maslach Burnout Inventory-Human Services Survey (MBI-HSS) may be considered a limitation of this study. In addition, the fact that the sample was composed mainly of women did not allow for an apprehension of the influence of gender in the appearance of burnout syndrome. However, it was perceptible that the non-uniformity of the groups, regarding support services, may have contributed to the more modest results obtained in relation to their influence on the emotional exhaustion, depersonalization and personal accomplishment variables.

As for future research, a replication of this study, at a national level, appears relevant, whilst taking into consideration the need for the composition of the study to be more homogeneous in relation to the sociodemographic and professional variables under study, for a better apprehension of their effects in the development of Burnout. It would be absolutely relevant to develop longitudinal studies centered on the evaluation of intervention programs adjusted to the reality and context being studied.

Burnout is considered one of the great contemporary challenges to the occupational health of professionals, with special emphasis for those professions involving assistance, and has underlying costs for the workers, not just at the individual level, but also at the family level and for the institutions themselves. Although the incidence is lower than that presented by health professionals, according to the levels presented we should not ignore that these present a threat. It is therefore imperative that delineate interventions adjusted to the context associated with care providers to the elderly and chronically ill.

\section{References}

Barría, J. (2003). Síndrome de Burnout en asistentes sociales del Servicio Nacional de Menores de la región metropolitana. Psykie, 12, 213-226.

Breihl, K. A., \& Nunes, M. L. T. (2012). Burnout em psicólogos-Quando o trabalho adoece. In Ribeiro J.; I. Leal, A. Pereira, P. Vagos, \& I. Direito (Eds.). Atas do $9^{\circ}$ Congresso Nacional de Psicologia da Saúde: Promoção da Saúde e doenças crónicas desafios à promoção da Saúde (pp. 1389-1396). Lisbon: Placebo, Editora, Lda.

Carlotto, M. (2011). O impacto de variáveis sociodemográficas e laborais na Síndrome de Burnout em técnicos de enfermagem. Revista Sociedade Brasileira de Psicologia Hospitalar, 14, 165-185.

Carvalho, V., Calvo, B., Martin, L., Campos, F., \& Castillo, I. (2006). Resiliencia y el modelo burnout-engagementen cuidadores formales de ancianos. Psicothema, 18, 791-796.

Da Silva, M., Marques, M., \& Da Silva Bruno, C. (2009). Avaliação da presença da Síndrome de Burnout em cuidadores de 
idosos. Enfermería Global, 16, 1-10.

Dias, S., Queirós, C., \& Carlotto, M. (2010). Síndrome de Burnout e fatores associados em profissionais da área da saúde: Um estudo comparativo entre Brasil e Portugal. Aletheia, 32, 4-21.

Ebling, M., \& Carlotto, M. S. (2012). Burnout Syndrome and Associated Factors among Health Professionals of a Public Hospital. Trends Psychiatry and Psychotherapy, 34, 93-100.

Gisbert, M., LosFayos, J., \& Montesinos, M. (2008). Burnout en fisioterapeutas españoles. Psicothema, 20, 361-368.

Gomes, A., Cruz, J., \& Cabanelas, S. (2009). Estresse Ocupacional em Profissionais de Saúde: Um Estudo com Enfermeiros Portugueses. Psicologia: Teoria e Pesquisa, 25, 307-318.

Grau, A., Flichtentrei, D., Suñer, R., Prats, M., \& Braga, F. (2009). Influencia de factores personales, profesionales y transnacionales en el Síndrome de Burnout en personal sanitario Hispanoamericano y Español (2007). Revista Espanhola Salud Pública, 83, 215-230. http://dx.doi.org/10.1590/S1135-57272009000200006

Grau, A., Suñer, R., \& García, M. (2005). Desgaste profesional en el personal sanitário y su relación con los factores personales y ambientales. Gaceta Sanitaria, 19, 463-470. http://dx.doi.org/10.1016/S0213-9111(05)71397-2

Kareaga, A., Exeberria, S., \& Smith, J. (2008). Evaluación del burnout y bienestar psicológico en los profesionales sanitarios del País Vasco. Revista de Psicologíadel Trabajo y de las Organizaciones, 24, 235-252.

Lyod, C., \& King, R. (2004). A Survey of Burnout among Australian Mental Health Occupational Therapists and Social Workers. Social Psychiatry and Psychiatric Epidemiology, 39, 752-757. http://dx.doi.org/10.1007/s00127-004-0808-7

Maroco, J. (2010). Análise Estatística. Com utilização do SPSS. Lisboa: Edições Sílabo.

Maslach, C., Schaufeli, W. B., \& Leiter, M. P. (2001). Job Burnout. Annual Review of Psychology, 52, 397-422. http://dx.doi.org/10.1146/annurev.psych.52.1.397

Noguera, L., \& Francês, F. (2008). Estudio descriptivo del Síndrome de Burnout en una muestra de professionales de enfermeria en el área sur de Gran Canária. Ansiedad y Estrés, 14, 101-113.

Oyefeso, A., Clancy, C., \& Farmer, R. (2008). Prevalence and Associated Factors in Burnout and Psychological Morbidity among Substance Misuse Professionals. BMC Health Services Research, 8, 39. http://dx.doi.org/10.1186/1472-6963-8-39

Pera, G., \& Serra-Prat, M. (2002). Prevalencia del síndrome del quemado y estudio de los factores asociados en los trabajadores de un hospital comarcal. Gaceta Sanitaria, 16, 480-486.

http://dx.doi.org/10.1016/S0213-9111(02)71968-7

Pereda-Torales, L., Celedorio, F., Vásquez, M., \& Zamora, M. (2009). Síndrome de Burnout en médicos y personal paramédico. Salud Mental, 32, 399-404.

Ribeiro, L., Gomes, A., \& Silva, M. (2010). Stress ocupacional em profissionais de saúde: Um estudo comparativo entre médicos e enfermeiros a exercerem em contexto hospitalar. In C. Nogueira, I. Silva, L. Lima, A. T. Almeida, R. Cabecinhas, R. Gomes, C. Machado, A. Maia, A. Sampaio, \& M. C. Taveira (Eds.), Actas do VII Simpósio Nacional de Investigação em Psicologia (pp. 1494-1508). Lisboa: Associação Portuguesa de Psicologia.

Roque, L., \& Soares, L. (2012). Burnout numa amostra de psicólogos portugueses da região autónoma da Madeira. Psicologia, Saúde \& Doenças, 13, 2-14.

Schaufeli, W. B., Leiter, M. P., \& Maslach, C. (2009). Burnout: 35 Years of Research and Practice. Career Development International, 14, 204-220. http://dx.doi.org/10.1108/13620430910966406

Schaufeli, W., \& Greenglass, E. (2001). Introduction to Special Issue on Burnout and Health. Psychology and Health, 16, 501510. http://dx.doi.org/10.1080/08870440108405523

Semedo, C. (2009). Bem-Estar Psicológico no Trabalho e Acidentalidade Laboral em profissionais de saúde. Santiago de Compostela: Universidade de Santiago de Compostela.

Silva, M., \& Gomes, A. (2009). Stress Ocupacional em profissionais de saúde: Um estudo com médicos e enfermeiros portugueses. Estudos de Psicologia, 14, 239-248.

Shirom, A. (1989). Burnout in Work Organizations. In C. L. Cooper, \& I. Robertson (Eds.), International Review of Industrial and Organizational Psychology (pp. 25-48). New York: Wiley.

Varoli, I., \& Souza, C. (2004). O sofrimento dos que tratam: Burnout em profissionais de saúde mental. In J. Ribeiro, \& I. Leal (Eds.), Actas do $5^{\circ}$ Congresso Nacional de Psicologia da Saúde: A Psicologia da saúde num mundo em mudança (pp. 691-697). Lisboa: ISPA.

Vicente, C. S., Oliveira, R. A., \& Maroco, J. (2013). Análise fatorial do Inventário de Burnout de Maslach (MBI-HSS) em profissionais portugueses. Revista Psicologia, Saúde \& Doenças, 14, 152-167. 
Scientific Research Publishing (SCIRP) is one of the largest Open Access journal publishers. It is currently publishing more than 200 open access, online, peer-reviewed journals covering a wide range of academic disciplines. SCIRP serves the worldwide academic communities and contributes to the progress and application of science with its publication.

Other selected journals from SCIRP are listed as below. Submit your manuscript to us via either submit@scirp.org or Online Submission Portal.
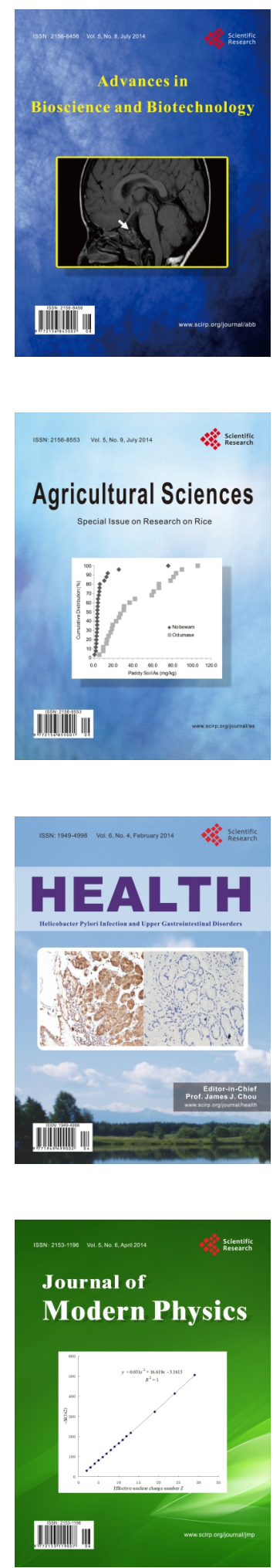
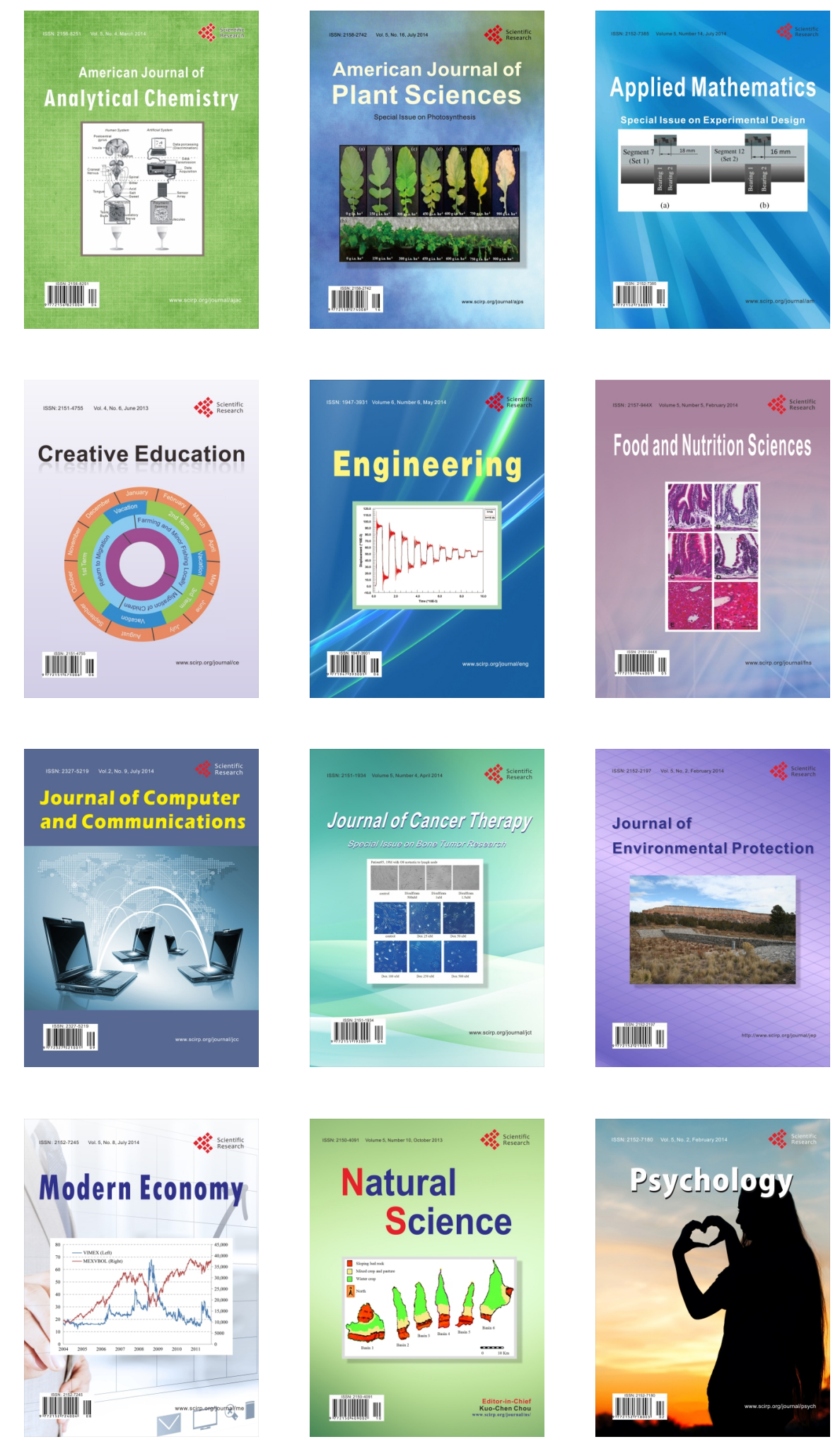